\title{
FEDERAL GRANTS AND THE PROBLEM OF FINANCING PUBLIC ASSISTANCE
}

\author{
Grorge A. Shipman* and Harold J. Saum $†$
}

\section{I}

The "emergency" is over. At least official pronouncements have repealed it in authoritative terms, citing statistics for nation-wide employment that somehow cannot blind even the casual observer to the poignant need on every hand. No longer will federal emissaries visit the "provinces" redoubling their demands for state relief money, to the mingled anger, chagrin, and amusement of local administrations. No longer will states find protection in the haggling methods of the horse-trader, nor will emergency preambles be either appropriate or sufficient to soothe the harassed citizen into new measures of taxation. From the federal standpoint the tapering-off process is well under way. But in the states and local units there is, in all too many instances, a definitely increased relief cost, and with it a prolonged fiscal emergency. ${ }^{1}$

The demobilization of relief is being done according to a plan, despite the impossibility of fitting the jigsawed segments into a complete picture. At the moment the federal government has ceased its grants for general relief and confines its expenditures to work projects for unemployed persons. Other problems of dependency have been treated in one way or another by the Social Security Act; still others have been left to whatever resources the separate states and their local units can devise. ${ }^{2}$

- B.A., I925, M.A., 1926, Wesleyan University; Ph.D., I93I, Cornell University. Research Associate, Princeton Local Government Survey. Instructor in Government, Cornell University, 1927-1930; Assistant Professor of Political Science, 1930-1935, Associate Professor, 1935, West Virginia University. Research Associate, Bureau for Government Research, West Virginia University, 1930-1935. Consultant, Legislative Committee on Efficiency and Economy, West Virginia, 1933. Technical Consultant to the Governor of West Virginia, 1933-1935. Consultant, Legislative Committee on Social Security Legislation, I936. Staff member, Committee on Economic Security, 1934.

†A.B., 1923, West Virginia Wesleyan College; M.A., 1927, LL.B., 1929, West Virginia University. Research Associate, Princeton Local Government Survey. Member of the West Virginia Bar. Field Investigator, Commissioner on Law Observance and Enforcement, 1930-1931. Instructor in Law, College of Law, West Virginia University, 1934. Research Assistant, Bureau for Government Research, West Virginia University, r934. Instructor in Political Science and Research Associate, Bureau for Government Research, West Virginia University, 1935 .

${ }^{1}$ For a revealing survey of the heavy relief burden placed upon state and local shoulders, see American Association of Social Workers, A Survey of the Immediate Relief Situation in Twenty-five States, (New York, 1936).

${ }^{3}$ See Rubinow, The Social Security Act: An Appraisal (March 1936) 35 NAT. Mun. Rev., 138; Shipman, Planning the Care of Unemployables (Jan. 1936) 35 id. 7- $\mathrm{xr}, 22$. See also Legal Research Section, Works Progress Admn., Legislative Trends in State and Local Responsibility for Public Assistance (Washington, D. C., March r936). 
To see the fiscal needs of state participation in those activities that are aided by the Social Security Act as an independent problem, is to disregard other equally insistent human needs. ${ }^{3}$ A rough approximation indicates that fully one-third of unemployable persons including the ill and large classes of the physically handicapped are not touched by the new act. At the same time the postulate that the states need care only for their unemployables because federal work programs provide for those able to work has yielded many contradictions. Employable persons have been refused jobs because allotments were exhausted; no provision was made for increased case-loads during winter months; and, in some states, pay was so low that supplemental relief was necessary to prevent undernourishment in many families. ${ }^{4}$ At best it appears that the widely-heralded federal aid can reach only a fraction of the total number of persons who are dependent upon state and local government for their - subsistence.

The needs of emergency relief called forth nearly every type of unsound financing. Heavier taxes were piled upón struggling business, and upon falling personal income. Bond obligations were contracted to supply current needs. Reserve funds were depleted and dedicated revenues were diverted. The consequence is a mad scramble of permanent, temporary and emergency adjustments, accumulated claims due pension funds, and bonded debt without capital security. ${ }^{5}$

Meanwhile other fiscal needs have gone on as always. Current services have been pruned, essential repairs postponed, and capital replacements suspended during the emergency period. These essential requirements cannot be held off indefinitely; in fact sound public administration demands that they be met to protect the investments of generations. At the same time, the warning is sounded that the heroic measures of relief financing were only a prelude to a permanent provision for welfare requirements that, for the time being at least, cannot be expected to fall far below depression needs.

It appears that, perhaps in all states, a definitely increased permanent revenue

'For discussions of the general problem, see Shipman, The Care of Unemployables in West Virginia (1935); New Jersey Conference of Social Work, $A$ Plan for a Coördinated and Permanent Public Welfare Department (Newark, N. J., Feb., 1936).

"See note I, supra; and study made by Catherine M. Dunn, reviewed in (March 1936) 14 TAx Magazine I 87.

"In the "mad scramble," all conceivable state, county and local sources were "tapped" or created for relief financing. Significant examples follow:

State: general revenues; liquor. funds; road and highway funds; motor registration and license fees; bonds and notes; transfer from public school equalization fund; surplus funds of Teachers' College; seed loan funds; horse racing fees; salary cuts; departmental funds; Teachers' Pension and Annuity Fund; sinking fund; income, inheritance, corporation, sales, luxury, gasoline, chain store, and numerous other taxes.

County: general fund; loans; bonds; highway funds; sheriff's fees and charges; sales, property, income, inheritance and other taxes.

Local: available funds; loans; bonds; public funds transfer; advertising, amusement, gasoline, property, and other taxes.

For complete details, see Federal Emergency Relief Administration, Digest of State Legislation for the Financing of Emergency Relief, MoNTHLY REPORT (May 1935). 
program will be essential. This means the restoration of trust funds to actuarial solvency, the liquidation of bonded relief debts, and the readjustment of diverted revenues. The short-sighted fiscal expedient of robbing Peter to pay Paul will end with the taxpayers' paying both Peter and Paul, and with interest added.

Where "temporary" and "emergency" taxes were imposed to meet the costs of dependency the taxpayer will probably have to accept these fiscal stepchildren as permanent boarders at the family table. In brief, emergency financing solved no problems. It merely postponed them and by doing so often confused them as well. Thus it happens that adjusting public assistance to a permanent status, even though state and local expenditures for these purposes may not be increased, will mean in many cases a patient untangling of badly snarled finances.

Can the states and their subdivisions pay their share of the costs of the services aided by the Social Security Act? If this question could be isolated and answered directly there would be fewer perplexities, but only by assuming artificial simplicities, can such certainty be risked. On the side of cost the federally-aided services are inextricably interwoven with all the other welfare activities of the states, and on the side of support they are only a few of many urgent demands upon public treasuries.

The lure of federal funds places a disproportionate emphasis upon the formalization of the aided services. The states' task is not simply to provide continuing and adequate care for the aged, the blind, the dependent children, and to fortify ancillary child welfare, maternal and child health and public health activities. The problem is rather to evolve a comprehensive, well-balanced public welfare program that will displace outgrown attitudes and methods of poor relief; that can reach the problems of dependency where and as they exist; and that can draw upon fiscal capacities that are most nearly adequate to afford effective services. The problem, though largely one of administration, is a fiscal one as well- the methods of financing are so intertwined with those of administration that the two become inseparable.

As the federally-aided services get under way, a considerable momentum, inevitably accumulating, will force constantly increasing expenditures. As a definite type of need is recognized, its treatment formalized, and the diminishing stigma of "poor relief" is removed by the gratuity of "pensions," mounting costs are certain. Apart from purely social implications this trend augurs a demand for public funds that may seriously stunt the development of adequate fiscal support for the entire welfare program. ${ }^{\circ}$

Further, there is the question of the sufficiency of federal aid. Although the financial need of the recipient states is to be taken into consideration in the allocation of part of the appropriations under Title $\mathrm{V}$ providing for maternal and child-health services and aid for neglected children and under Title VI for aid to public-

${ }^{\circ}$ Pertinent is the statement of Murray Latimer, Hearings before the House Committee on Ways and Means on H. R. 4120 (Economic Security Act) 74th Cong., Ist Sess. (1935) at pp. 219 et seq. 
health services, ${ }^{\sigma^{2}}$ the grant-in-aid titles of the Social Security Act which will entail the largest financial outlay, viz. Title I providing for old-age assistance, Title IV, aid for dependent children, and Title $\mathrm{X}$, aid for the needy blind, authorize federal appropriations only on a matching basis. The matching basis, whether dollar for dollar or one dollar for two, is still no important advance beyond the methods of previous federal grants, and the more conventional devices used by states for the distribution of funds among their subdivisions. As an effort to supplement state resources the proportional grant has the pronounced weakness of supplying additional funds in direct relation to the amounts available in the states. Such a method neither equalizes state capacities in any significant manner, nor takes cognizance of the potential need for services within the states, unless, of course, the relative amounts of state appropriations are themselves to be regarded as fairly accurate measures of the relative need for service.

As a general rule the matching grant (up to the stated maxima), does nothing to equalize the conditions of those states that are scarcely able to furnish even a modest amount of assistance, with those whose aid payments were maintained upon a reasonably adequate level before the enactment of the Social Security Act. The reliance upon a straight matching basis, as the measure of federal grants, precluded the initiation in the field of public care of methods of fund distribution similar to those developed with success in England, and to those attempted, though in an opportunistic and disorderly way, by the Federal Relief Administration. ${ }^{7}$

The shortcomings of the matched grant are of fiscal importance because they offer little help to the state legislators who are soberly inspecting the figures for caseloads and present state taxes and are wondering how, with no more than a direct matching of state appropriations, the cost of dependency can be met in any important way. A desire to increase state resources to the utmost by realizing upon the maximum of federal aid defeats its own purpose by concentrating state outlays upon only a phase of the entire problem at the probable expense of equally deserving activities.

It develops that the task of the state financing of public assistance is cluttered with many incidental but unavoidable issues. To avoid them is to postpone problems that must be solved, and to face them squarely may bring about the anomalous situation of declining to take advantage of the full possibilities of the Federal Act. ${ }^{8}$

ou Social Security Act of Aug. I4, I935, 49 STAT. 620, Tit. V, $\$ \$ 502$ (b), 521 (a); Tit. VI, $\$ 602$ (a).

${ }^{7}$ See Horack, Federal-State Coöperation for Social Security: The Grant-In-Aid (1935) 30 ILL. L. REv. 292.

"Notice the impressive list of "uncertainties" regarding the demands for relief and public assistance which New Jersey and its political subdivisions must face:

I. Uncertainty regarding the future policy of the federal government relative to the appropriation of federal funds for direct relief.

2. Uncertainty regarding the permanence of the present work relief program of the Federal W.P.A. and P.W.A.

3. Uncertainty regarding the number of employable persons in need of public assistance whose needs will not be met by the federal work program. 


\section{III}

As the states proceed with operations under the social security plan, the following trends will become more and more pronounced:

One. There will be a marked tendency to avoid further borrowing for public relief purposes.

Two. There is developing a definite and necessary coöperative fiscal relationship between state and local governments.

Three. There is the cry for "economies" and the conservation of every resource for the purpose of financing public assistance.

Four. There is the hard fact that new taxes will, in many cases, be essential to carry out the obligations of the Social Security Act.

One. The matter of borrowing is easy to understand. Not only have the states and localities bonded themselves heavily for emergency relief purposes, but they have pledged important sources of revenue for payment of the obligations. ${ }^{9}$ This has made their fiscal systems inflexible, and any further borrowing would tend, in many cases, to "dedicate" still more essential sources or even to burden still further hardpressed general property.

There is another point. Capital outlays-particularly for institutions, schools and roads-have in many places suffered enormously during the past few years. While minor additions and improvements may be made from current revenues, major replacements must of necessity turn to some form of borrowing. Even though this be done sparingly, it will tend to restrict additional bond issues for more or less ephemeral purposes, and will reëmphasize the principle that public borrowing should be based upon permanent assets.

Two. The coöperative fiscal relation between state and local government is rooted in necessity. In the first place the Social Security Act requires that, the state shall participate in the financing of most types of public assistance. ${ }^{10}$ When this standard is set over against the traditional attitude that the care of the poor is entirely a local

4. Uncertainty pending judicial action upon the constitutionality of the Social Security Act.

5. Uncertainty regarding the amount of federal funds which may be available for relief purposes as outlined in the Social Security Act.

6. Uncertainty as to the possible readjustment of the present tax system in New Jersey which may alter the traditional financial responsibilities of the municipajities, counties and the state. New Jersey Conference of Social Work, op. cit., supra note 3 .

${ }^{\circ}$ Following is an indication of amounts borrowed and revenues pledged in selected states: ILliNors: $\$ 17,000,000$, Cook County bonds to be serviced by property levy; $\$ 30,000,000$, state bonds, financed by motor fuel tax, counties and cities to divert their share of motor fuel taxes in proportion to percent of bond procceds received; $\$ 20,000,000$, state bonds, financed from counties' allotment of motor fuel tax. WASHINGTON: $\$ 10,000,000$, state bonds, financed by diversion of $4 / 10$ of I cent of the gasoline tax. NEW JERSEY: $\$ 20,000,000$, state bonds, serviced from motor fuel tax; $\$ 5,000,000$, state bonds, serviced from motor fuel tax, or if that is insufficient, from property tax; $\$ 10,000,000$, state bonds, serviced from liquor taxes and funds resulting to the state from inheritance tax litigation, and if these sources are insufficient bonds to be serviced by state property tax. MaryLand: $\$ 12,000,000$, state bonds, serviced by property levy of 5 cents per \$roo assessed valuation for years I934-49 inclusive. California: \$20,000,000, state bonds, financed by withholding counties' share of motor vehicle fuel tax moneys, unless other means of repaying same are provided.

${ }^{10}$ Social Security Act, Tit. I, $\$ 102$ (a) (2); Tit. IV, $\$ 402$ (a) (2); Tit. V, $\$ 503$ (a) (1), 513 (a) (I); Tit. X, $\$ 1002$ (a) (2); cf. Tit. V, $\$ 521$ (a); Tit. VI, $\$ 602$. 
responsibility, and the hard fact that many of the so-called old-age and mothers' "pension" laws of the last fifteen years have been almost inoperative because the traditional local area was expected to furnish the funds, it is easily seen that new adjustments are unavoidable. ${ }^{11}$

During the early years of the depression, moreover, the apparent fact that localities could not carry their relief costs led to varying degrees and methods of state assistance. In some instances there was a complete displacement by the state of both the local poor relief machinery and local fiscal support. These adjustments were based upon administrative and financial necessity. Localities could not effectively manage, nor could they finance, public aid,-at least not without definite state guidance and assistance.

Thus previous experience demonstrates that if these services are to be rendered with any degree of uniformity, state finances must bear a considerable share of the load. Some localities still find sufficient revenues in their property taxes to maintain welfare activities, but many more find that a high case load of dependents means also restricted income for assistance. ${ }^{12}$

But the method of state participation is still far from a satisfactory solution. Generally speaking, state grants like the federal subsidies are measured directly by the amounts made available by the smaller units. If more state funds are to be spent, more local revenues must be found. The difficulty with this principle is that the degree of state financing is measured by the amount of local funds available, not by the need for welfare services. In most instances the real need is for a method of distribution in inverse proportion to local capacities.

Three. The trend toward a close integration of state and local revenues for the support of public assistance reflects the very general conviction that local revenues must be exhausted before state funds are utilized. Apart from reaffirming the principle of primary local responsibility there is also the firm belief that state taxes must be kept down and that to do this every available local revenue should be used.

"Of the thirty "old-age pension" laws in operation in 1934 , little or no payments were bcing made in Kentucky, Nebraska, North Dakota and West Virginia. In eight states (Iowa, Maryland, Michigan, Minnesota, Nevada, Utah, Washington, Wisconsin) less than five percent of the total number of persons of eligible age were receiving aid. (It is estimated that fifteen percent of the total number of eligible age will qualify for assistance in the states now commencing this service under the Social Security Act.) In eight states (Arizona, Colorado, Delaware, Idaho, Indiana, Michigan, Montana, and Utah) aid averaged less than \$ro.00 per month. In five more (Iowa, Minnesota, New Jersey, Ohio and Wyoming) the average was less than $\$ 15.00$ per month. See Hearings, supra note 6. Table 14, p. 77.

of the forty-five state "mothers' pension" laws technically in operation in r934, two (Mississippi and Arkansas) were inoperative. While average aid per case is not given, less than one thousand children were being benefited in each of nineteen states. See id., Table 18 , p. 80 .

${ }^{20}$ Available materials indicate that among the states which have qualified under the Social Security Act, about one-half of the approved services are supported jointly from state and local funds. The proportions of this support range from a five percent state contribution in New Hampshire to 84 percent in Wisconsin. State-local sharing of cost is provided, among others, in Alabama (old-age and dependent children), Maine (old-age and dependent children), Maryland (old-age), New Hampshirc (old-age and blind), Washington (dependent children), Wisconsin (old-age, blind and dependent children), Wyoming (old-age). Data obtained from Legal Research Section, Division of Social Rescarch, Works Progress Administration, Washington, D. C. 
On the side of the state this same viewpoint is placing a strong emphasis upon every possible curtailment,-savings from other operations that can be turned back to the treasury to support welfare. Old line departments and traditional activities are facing the need of demonstrating to the legislature and the state that their expenditures are as deserving as is the care of the indigent. During the early years of the depression the states and localities learned that relief is expensive business, and however necessary from the human view, is tremendously difficult to administer so that only those whose need is genuine will be accorded aid. In the beginnings of the new public assistance program, consequently, there is the heartfelt demand that faithful, competent administration grant public aid only to those actually in need, and then only to the extent of their need. At the same time, there is the equally insistent demand that every present resource be exhausted before new income is used.

The impression grows upon the observer that state tax systems are likely to be adjusted or "reformed" by off-hand methods and possibly by inadvertence., The states are not undertaking any comprehensive revision of their revenue plans in the interest of equity. Instead they are plucking surpluses, draining dedicated revenues, and resorting to any other expedients that can furnish additional money for public assistance without asking more of the taxpayer. The eontinuation of such a trend may before many years produce an even more seriously muddled condition of state finances than now exists.

Four. But with every effort at avoiding new revenues there will remain, in the vast majority of states, the inescapable need for new taxes. "When this requirement is faced the prospects for new indirect taxes are excellent. General property is already overburdened, at least the property owner believes this so thoroughly that an effort to increase his levies would have rough going. Indirect taxes, consequently, seem the easy way out. ${ }^{13}$ It has already been indicated that a good many states have resorted to this expedient for the financing of relief. In any case it seems a safe guess that as the cost of public assistance increases there will be a general revival and perpetuation of those incidental revenues that previously were regarded as desirable only when no other way seemed possible.

New taxes will bring other implications. As is usually the case when new revenues are needed without delay, the resort will doubtless be to those taxes promising a quick easy return with a minimum of administrative effort and complication. Little emphasis is placed upon the essential equity of the new levy-whether it is retrogressive, and whether it reaches those best able to pay. Such considerations are

\footnotetext{
${ }^{23}$ But there are legal complications perplexing the use of some indirect state taxes. The perennial issue between state constitutional provisions requiring an intrinsic uniformity and personal income taxation is well known. For a recent decision holding a state income tax invalid, among other reasons, because of a difference in exemption based on marital state, see Kelly v. Kalodner, I81 Atl. 598 (Pa. 1936). How confusing the effect of federal constitutional limitations may be in a rather new field of state taxation is well illustrated by recent decisions of the United States Supreme Court with respect to chain store taxation. See Notes (I935) 45 Y YLE L. J. 314; (1935) 21 Iowa L. Rev. 93.
} 
swept aside, and as long as enough funds will be realized, nothing else matters very much.

Another side of the financing of assistance reflects what may become a serious issue of values. During the past few years perhaps the most insistent fiscal issue in the states has been tax limitation, that is, the reduction of real property levies to a more or less arbitrary maximum, with reliance upon expanded state indirect taxes, and reductions in public expenditures to balance off the "savings." 14 What has actually happened is that expenditures have remained about the same, as one would expect; but indirect taxes have been expanded many fold to assure the continued operations of schools, the maintenance of roads and the upkeep of local government. While the trend toward the limitations seems to have slowed down considerably it is still far from a standstill, and in the states that have already undertaken the adjustment indirect taxes seem to be reaching the saturation point.

When public assistance, demanding new revenue, meets the counter force of general property seeking relief from heavy taxation, one or the other must yield. To quote odds on such a contest would indeed be risky business because of the infinite number of variable factors that fix the values of each state and will condition its judgment as to which is worth more, expanded public assistance or reduced general property levies. To hazard a rather loose prediction, it may be said that to the extent that the needs of public assistance are met by new state taxes, to the same degree the relief of general property will be inhibited. This will be true whether new taxes or local levies are used for the purposes of the welfare services.

\section{IV}

A long-run view appreciates that the whole tax problem is considerably involved. Federal policies of taxation make it difficult for many states to find other sources able to carry the load. There is, moreover, the whole question of the competitive or noncompetitive status of industry within the state, and the effect upon its interstate business of increased taxation. Ultimately there arises the necessity for an integration of tax systems-national, state and local-that will take into consideration the diffcult maladjustments that mar so much of the present tax structure. ${ }^{15}$ Such an effort deserves the heartiest support; but it must be candidly admitted that efforts at readjustment will be postponed to the extent that the elasticity is taken from tax systems by the strains of rapidly expanded revenues, and accumulated obligations for which present and future collections are pledged.

"A detailed "case history" of the West Virginia experiment with tax limitation is given in Sly and Shipman, Tax Limitation in West Virginia, Public Afrarrs Burl. No. 8; and Sly, Burke and Parry, Indirect Taxes, Public Affairs Bull. No. 9, (Bureau for Gov't Research, West Virginia Univ., 1933). For a comprehensive treatment of tax limitation laws and the experience of states under them, see Property Tax Limitation Laws, Public Adm. Service, Pub. No. 36, (Chicago 1934). See also articles by F. L. Bird, J. F. Sly, S. J. Barrick, S. E. Leland, A. H. Hall, and J. P. Jensen in the November, 1935, issue of the National Municipal Review.

${ }^{25}$ For an important study of the problem of conflicting federal and state taxes, sec INTERSTATz CoMM'N on Conflicting Taxation, Conflicting Taxation, (Chicago, 1935). 
It seems amply evident that the citizen is in for increased state taxes-particularly luxury, nuisance, and sales levies-to support.programs of assistance. These new revenues will be in addition to federal payroll and other taxes, and the normally increasing needs of all public activities. All in all, the situation presents an unusual opportunity to those fiscal experts who are adept in the fine art of painless extraction. ${ }^{16}$

${ }^{16}$ It is still too soon to see the fiscal consequences and implications of state participation in the social security plan. Even in those states that have already received federal aid under the new act, adjustments in revenue, other expenditures, and the cost of the service itself cannot be clearly seen until another year has elapsed. The generalizations contained in the text are believed to be sound whether the particular state in question previously maintained reasonably extensive services or had none at all. In New Jersey, for example, the state cost of old-age assistance and aid for dependent children has been paid from state emergency .relief funds. Consequently the permanent financing of public assistance is only part of the whole question of supporting all types of public care. In West Virginia, where old-age assistance was never paid and "mothers' pensions" granted only in a most inadequate way, it appears that even a modest expenditure for these purposes would much more than double the amounts now granted through the relief administration. Since the present cost of relief alone seems beyond the reach of state and local treasuries, the adjustments required in initiating the federally-aided services are rather perplexing. 